No. 4816 February 17, 1962

of the two-dimensional problem (Dr. H. A. Lauwerier, Amsterdam); the analogue approach-the mathematical formulation of tidal problems in analogue computation (Dr. J. C. Schonfeld, The Hague); the numerical approach-a review of computing theory (Dr. H. O. Kreiss, Sweden); the numerical approach -review of computing practice (Prof. W. Hansen); the numerical approach-review of operators (M. B. Abbott, Denmark); alternative approaches-the method of characteristics (Dr. J. C. Schonfeld); alternative approaches - characteristics and computers (M. B. Abbott). Further information can be obtained from Dr. J. R. Rossiter, Tidal Institute and Observatory, The Observatory, Birkenhead, Cheshire.

\section{Institution of Electrical Engineers}

SIR John HACkrNG has been elected to honorary membership of the Institution of Electrical Engineers for his many contributions to the development of electricity supply in Great Britain and throughout the world, and for his long service to the Institution.

The fortieth award of the Faraday Medal has been made to Sir Basil Schonland for the outstanding part he has played in the development of electrical science and engineering, in particular in the field of nuclear power.

\section{The Night Sky in March}

NEw moon occurs on Mar. 6d. 10h. 31m. U.T. and full moon on Mar. 21d. 07h. 56m. The following conjunctions with the Moon take place: Mar. 3d. $22 \mathrm{~h}$., Saturn $1^{\circ}$ S.; Mar. 4d. 13h., Mercury $0.7^{\circ} \mathrm{S}$; Mar. 5d. 02h., Mars 0.5 $5^{\circ}$ S.; Mar. 5d. 03h., Jupiter $0 \cdot 1^{\circ}$ S.; Mar. 12d. 05h., Aldebaran 0.6 $6^{\circ}$ S.; Mar, 18d. 17h., Regulus $0.6^{\circ}$ S.; Mar. 3Id. 1lh., Saturn $1^{\circ}$ S. In addition to these conjunctions with the Moon, Mars is in conjunction with Jupiter on Mar. 6d. 14h., Mars being $0.4^{\circ}$ S., Mercury with Jupiter on Mar. 13d. 04h., Mercury being $1^{\circ}$ S., and Mercury with Mars on Mar. 18d. 17h., Mercury being $1^{\circ} \mathrm{S}$. Mercury is too close to the Sun for observation. Venus is an evening star, setting about an hour after the Sun. Mars, Jupiter and Saturn are all morning stars, but are too elose to the Sun for observation. Occultations of stars brighter than magnitude 6 are as follows, observations being made at Greenwich: Mar. 1ld. 22h. 51.4m., $\gamma$ Tau. $(D)$; Mar. 18d. 16h. $02 \cdot 2 \mathrm{~m}$., $\alpha$ Leo. $(R)$. There is also an occultation of Mercury, visible at Greenwich, Mar. 4d. $13 \mathrm{~h} .13 \cdot 7 \mathrm{~m}$. $(D)$, Mar. 4 d. $14 \mathrm{~h} .19 \cdot 4 \mathrm{~m} .(R) . \quad D$ and $R$ refer to disappearance and reappearance, respectively. The vernal equinox occurs on Mar. 21d. 02h.

\section{Announcements}

THE Linnean Gold Medals for 1962, awarded by the Linnean Society of London, are to be presented at the anniversary meeting of the Society on May 24 to Dr. N. L. Bor, formerly assistant director of the Royal Botanic Gardens, Kew, and to Prof. G. Gaylord Simpson, Museum of Comparative Zoology, Harvard College, Cambridge, Mass.

Dr. B. N. Brockнouse, Atomic Energy of Canada, Ltd., has been awarded the Oliver E. Buckley Prize for Solid-State Physics for his work in the field of phonon-spectra and spin-wave spectra of solids by scattering of neutrons.

Discovery is offering two prizes, each of $£ 100$, for essays on the subject "What is Science For?" One prize will be awarded to a scientist, and one to a non-scientist. Entry forms and further information can be obtained from Discovery Essay Competition, Mercury House, 103-119 Waterloo Road, London, S.E.1.

A FUND is to be established as a memorial to Dr. Gertrude L. Elles of Newnham College, Cambridge. It has been suggested that the fund should be used to provide grants for students of geology or geography for travel or field work, or to defray the expenses of publishing original work. Subscriptions should be sent to Mrs. A. H. Quiggin, 8 Grantchester Road, Cambridge.

THE managing trustees of the Drummond Trust are offering a senior Drummond Fellowship, tenable for two years and valued at $£ 1,100$ a year, for research in nutrition. Further information can be obtained from the Honorary Secretary, Drummond Trust, University College, Gower Street, London, W.C.1.

AN informal discussion on "Inhibition of Gaseous Free Radical Chain Reactions" is to be held in the University of Cambridge during April 12-13. Further information can be obtained from Dr. B. G. Gowenlock, Department of Chemistry, University of Birmingham, Birmingham 15.

A MeEting on "The Basic Science of Electrical Ceramics", arranged by the basic science section of the British Ceramic Society, is to be held in London during April 4-5. Further information can be obtained from Dr. J. P. Roberts, Houldsworth School of Applied Science, The University, Leeds 2.

The fifteenth Laboratory Animals Centre congress will be held at the Royal Veterinary College, London, during April 9-10. Further information can be obtained from the Laboratory Animals Centre, Medical Research Council Laboratories, Carshalton, Surrey.

A symposrum on "Enzyme Mechanisms in Active Transport Systems", arranged by the British Biophysical Society, is to be held at the Middlesex Hospital Medical School on March 10. Further information can be obtained from Dr. R. D. Keynes, Agricultural Research Council, Institute of Animal Physiology, Babraham, Cambridge.

A CONFERENCE, arranged by the Scottish branch of Aslib, is to be held in Perth during March 16-17. The lectures to be given will include: "Writing the Literature of Science" (Mr. A. Clow); "Preparing Seientific Material for the Press" (Mr. Beck); "Publishing Scientific and Technical Material" (Mr. D. Ainslie Thin); "Bookbinding Standards and Developments" (Mr. D. Moncur); "Foreign Publications: Availability and Translation" (Dr. D. J. Urquhart). Further information can be obtained from Mr. H. Greenshields, 27 Sweyn Road, Thurso, Caithness.

Errata. The illustration to the article "Preservation of Cells in Tissue Culture" in Nature of February 10 , p. 549, has been reversed. In its present form the caption should read "... Top left, glycerol, seventh day; top right, glycerol, fourth day; bottom left, dimethyl sulphoxide, seventh day; bottom right, dimethyl sulphoxide, fourth day".

The Editor has been informed by Dr. A. D. Bangham that in his article entitled "Phospholipids and Sulpholipids" (Nature, 192, 807; 1961) the third line from the end of the second paragraph should read ". . . the trimannosides alone being almost as effective as $B C G$...", and not ". . . the dimannosides ..." as printed. 